\title{
THE RELATIONSHIP BETWEEN SERUM LEVEL OF MALONDIALDEHYDE AND PROGRESSION OF COLORECTAL CANCER
}

\author{
Ismar Rašić ${ }^{1}$, Azra Rašić ${ }^{2}$, Goran Akšamija ${ }^{1}$ and Svjetlana Radović ${ }^{3}$ \\ ${ }^{1}$ Department of General and Abdominal Surgery, Sarajevo Clinical Center, University of Sarajevo, \\ Sarajevo, Bosnia and Herzegovina; ${ }^{2}$ Department of Oncology, Sarajevo Clinical Center, University of Sarajevo, \\ Sarajevo, Bosnia and Herzegovina; ${ }^{3}$ Department of Pathology, Faculty of Medicine, \\ University of Sarajevo, Sarajevo, Bosnia and Herzegovina
}

\begin{abstract}
SUMMARY - The purpose of the study was to assess the level of serum malondialdehyde (MDA) concentration and its association with the stage and histopathologic sizes of colorectal cancer (CRC). One hundred and two patients having undergone surgical treatment of CRC between January 2014 and December 2015 were included in this cross-sectional study. The patients were divided into four groups (stage I-IV) according to the TNM classification. Control group included 30 subjects with no signs of malignancy and inflammatory diseases. In each patient, preoperative blood samples were obtained for determination of MDA concentration by ELISA immunoassay. Serum levels of MDA were progressively increased in patients with $\mathrm{CRC}$, reaching the highest value in the fourth stage of CRC. Serum concentrations of MDA were significantly higher in pT4 group as compared with pT3 and pT2 groups of CRC patients $(\mathrm{p}<0.01)$. Significantly higher levels of MDA were found in the N1 and $\mathrm{N} 2$ groups of CRC patients as compared with N0 group, as well as in patients with metastatic disease as compared with those without metastasis ( $\mathrm{p}<0.001$ ). In conclusion, the progression of CRC is associated with a significant increase in serum MDA levels.
\end{abstract}

Key words: Colonic neoplasms; Oxidative stress; Malondialdehyde; Cross-sectional studies

\section{Introduction}

Colorectal cancer $(\mathrm{CRC})$ is a neoplastic process that occurs in colon tissue. There are about one million new cases diagnosed each year, making CRC the third most common malignant tumor in human pathology around the world and the second leading cause of death due to malignant disease ${ }^{1}$.

Colorectal cancer is a heterogeneous disease that occurs in only partially known complex sequence of molecular events. Oxidative stress is one of the mecha-

Correspondence to: Assist. Prof. Ismar Rašić, MD, PhD, Department of General and Abdominal Surgery, Sarajevo Clinical Center, University of Sarajevo, Bolnička 25, 71000 Sarajevo, Bosnia and Herzegovina

E-mail: rasicismar@gmail.com

Received March 27, 2017, accepted February 19, 2018 nisms involved in the process of carcinogenesis. It is known that reactive oxygen compounds cause oxidative modification of nucleotide bases in the DNA (e.g., oxidation of thymine, cytosine, adenine and guanine), which can lead to carcinogenesis through the mutagenic potential of modified nucleotide bases ${ }^{2}$. The reactive intermediates, produced by oxidative stress, alter the structure of the membrane and cause lipid peroxidation of polyunsaturated fatty acids (PUFAs). Free radicals incurred during lipid peroxidation have some local effects due to its short life but their degradation products may serve as 'oxidative stress second messengers' due to the longer half-life and their ability to diffuse from the place of their origin. These decomposition products, mainly aldehydes such as malonaldehyde, hexanal, 4-hydroxynonenal or acrolein, gain a lot of attention because they are the most reactive com- 
pounds $s^{3,4}$. Malondialdehyde (MDA) is one of the most common and most harmful products of lipid peroxidation, which may lead to cell damaging, reacting with the free amino groups of proteins and nucleic acids, with the target mutagenic activity at the site of guanine in the DNA sequence ${ }^{5,6}$. Therefore, determination of MDA can be used to estimate the intensity of oxidative stress or damage caused by lipid peroxidation.

The role of oxidative stress in the pathogenesis and development of human CRC is suggested in different reports. Gastrointestinal tract is particularly susceptible to an attack by reactive oxygen species that lead to carcinogenesis. However, information about the biochemical alterations in the tissue and blood and their correlation with clinical stage of the disease is lacking ${ }^{7}$. The aim of the study was to analyze the concentration of MDA in the serum of patients in various CRC stages and to determine the relationship between this biomarker and stages, as well as histopathologic sizes of CRC estimated on the basis of preoperative, intraoperative and histologic findings (TNM classification), and to determine whether MDA has predictive significance in disease progression compared to histopathologic findings obtained after surgical resection of the tumor altered organ.

\section{Materials and Methods}

The cross-sectional study involved 102 patients of both genders with histologically confirmed CRC, admitted between January 2014 and December 2015 at the Department of General and Abdominal Surgery, Sarajevo Clinical Center, University of Sarajevo, for surgical-oncologic treatment of CRC. Patients with evidence of neoplasm on an organ that was not linked to $\mathrm{CRC}$, patients with an active infection, and patients with connective tissue diseases were excluded from the study. Based on the CRC stages, patients were divided into four groups: stage I (10 patients), stage II (30 patients), stage III (33 patients) and stage IV (29 patients). Determining the stage of colorectal neoplasms was carried out by the TNM staging system, using standard radiological examinations: chest $\mathrm{x}$-ray, ultrasound (US) and computed tomography (CT) of the abdomen and, if necessary, other radiological imaging. Control group consisted of 30 patients of the appropriate age and gender, without clinical and laboratory signs of malignant or inflammatory disease. The study protocol was approved by the local Ethics Committee. The study was carried out following the Declaration of Helsinki. A written informed consent was obtained from all patients.

Malondialdehyde concentration was analyzed at the Center for Cytogenetics and Molecular Medicine, Faculty of Medicine in Sarajevo, from serum samples (100 mL serum per sample) using a competitive enzyme immunoassay (ELISA). Preoperative blood samples were obtained and all serum samples were stored at $-80{ }^{\circ} \mathrm{C}$ until analysis. Testing was performed using a commercial kit for estimation of the overall level of MDA (USCN Life Science Inc., US-CEA597GE, Houston, USA). Reading of the results is carried out at $450 \mathrm{~nm}$ on a plate reader STAT FAX 2100 (USA). The measured MDA concentration was expressed in nanograms per milliliter $(\mathrm{ng} / \mathrm{mL})$.

Surgical treatment of CRC was performed as part of the therapeutic process. The oncologic surgery principle of en bloc resection of the organ with associated lymph-vascular arcade was performed.

After macroscopic examination of the gut sample obtained by surgical resection, samples of the tumor mass and lymphatic nodes were collected for microscopic analysis, which included determination of the histologic type of malignancy (categorization according to the World Health Organization), the depth of tumor invasion in the intestinal wall (pT), and the number of lymph nodes infiltrated with cancerous tissue $(\mathrm{pN})$. CRC stages were determined according to the TNM classification of the American Committee for Cancer (American Joint Committee on Cancer, AJCC) in 2010, in which " $T$ " marks the degree of the intestinal wall invasion, "N" the level of lymph node involvement, and "M" means metastasis and spread staging; staging of the tumor is marked with numbers from I to IV.

Statistical analyses were performed by the MedCalc Software for Windows, version 12.6.1.0 (Mariakerke, Belgium). The normality of data distribution was determined by Kolmogorov-Smirnov test. Continuous variables were presented as mean \pm standard deviation (SD) and compared by using the t-test for independent samples when showing normal distribution. Mann-Whitney U test was used for results not displaying normal distribution or for comparison of nonparametric data. ANOVA and Kruskal-Wallis test were used for statistical evaluation of more than 3 groups. Multiple regression analysis was used to exam- 
ine the impact of MDA on the stage, depth of CRwall invasion ( $\mathrm{pT}$ ) and carcinoma infiltration of lymph nodes. The level of significance was set at $\mathrm{p}<0.05$.

\section{Results}

The mean age of CRC patients (60\% male and $40 \%$ female) was 66.2 (range 47-78) years, with no statistically significant difference between male and female patients (65.04 vs. 64.3 years). The largest number of CRC patients were in the $\geq 70$ age group (43.1\%), followed by the $61-70$ age group (31.4\%). Table 1 depicts characteristics of the study patient population.

The most common site of colon cancer was the rectum area (34 patients, 33.3\%), followed by the sigmoid colon (22 patients, $21.5 \%$ ), while the least common area was the cecum (2.9\%). Adenocarcinoma was confirmed histologically in all patients with colon cancer, of which grade 2 was most common $(70.6 \%$ of patients). Concerning depth of the intestine wall invasion, $18(17.7 \%)$ patients had tumors involving the muscularis propria (pT2), 59 (57.8\%) patients had tumors involving the serosa without involvement of other organs (pT3), while 25 (24.5\%) patients had the tumor that penetrated the visceral peritoneum (pT4).

Compared to the regional lymph nodes, metastases in 1-3 regional lymph nodes (N1) were found in 35 (34.3\%) patients, metastases in 4 or more regional lymph nodes (N2) in $25(24.5 \%)$ patients, while no lymph node tumor process was observed in 42 (41.2\%) patients. Distant metastases were found in 29 (28.4\%) patients, mostly liver metastasis (26 patients).

Table 1. Demographic and clinical characteristics of study subjects

\begin{tabular}{|c|c|c|c|c|}
\hline & & $\begin{array}{l}\text { Control } \\
(\mathrm{n}=30)\end{array}$ & $\begin{array}{l}\text { Colorectal cancer } \\
(\mathrm{n}=102)\end{array}$ & $\mathrm{p}$ \\
\hline Age (years), median (min, $\mathrm{m}$ & & $54.1(41-78)$ & $66.2(47-78)$ & 0.041 \\
\hline Gender, n (\%): & & & & \\
\hline $\begin{array}{l}\text { Male } \\
\text { Female }\end{array}$ & & $\begin{array}{l}14(46.7 \%) \\
16(52.3 \%)\end{array}$ & $\begin{array}{l}61.2(60 \%) \\
40.8(40 \%)\end{array}$ & - \\
\hline Localization of CRC & \begin{tabular}{|l|} 
Cecum \\
Ascendens \\
Transversum \\
Descendens \\
Sigmoid \\
Rectosigmoid \\
Rectum
\end{tabular} & & $\begin{array}{l}3(2.9 \%) \\
15(14.7 \%) \\
3(2.9 \%) \\
6(5.9 \%) \\
22(21.5 \%) \\
19(18.6 \%) \\
34(33.3 \%)\end{array}$ & $\begin{array}{l}- \\
- \\
- \\
- \\
- \\
- \\
-\end{array}$ \\
\hline Histologic classification & $\begin{array}{l}\text { Adenocarcinoma } \\
\text { grade I } \\
\text { grade II } \\
\text { grade III } \\
\text { grade IV }\end{array}$ & & $\begin{array}{l}11(10.8 \%) \\
72(70.6 \%) \\
14(13.7 \%) \\
5(4,9 \%)\end{array}$ & $\begin{array}{l}- \\
- \\
- \\
-\end{array}$ \\
\hline Depth of CR-wall invasion & $\begin{array}{l}\text { pT2 } \\
\text { pT3 } \\
\text { pT4 }\end{array}$ & & $\begin{array}{l}18(17.7 \%) \\
59(57.8 \%) \\
25(24.5 \%)\end{array}$ & $\begin{array}{l}- \\
- \\
-\end{array}$ \\
\hline Lymph node invasion & $\begin{array}{l}\text { N0 } \\
\text { N1 } \\
\text { N2 }\end{array}$ & & $\begin{array}{l}42(41.2 \%) \\
35(34.3 \%) \\
25(24.5 \%)\end{array}$ & $\begin{array}{l}- \\
- \\
-\end{array}$ \\
\hline $\operatorname{MDA}(\mathrm{ng} / \mathrm{mL})$ & & $\begin{array}{l}26.95 \\
(17.4-31.2)\end{array}$ & $\begin{array}{l}59.57 \\
(16.5-69.5)\end{array}$ & $<0.001$ \\
\hline
\end{tabular}

Data are presented as median (min, max), absolute numbers and percentages; MDA = malondialdehyde; $\mathrm{CRC}=$ colorectal cancer 
Table 2. Malondialdehyde concentration in patients with colorectal cancer

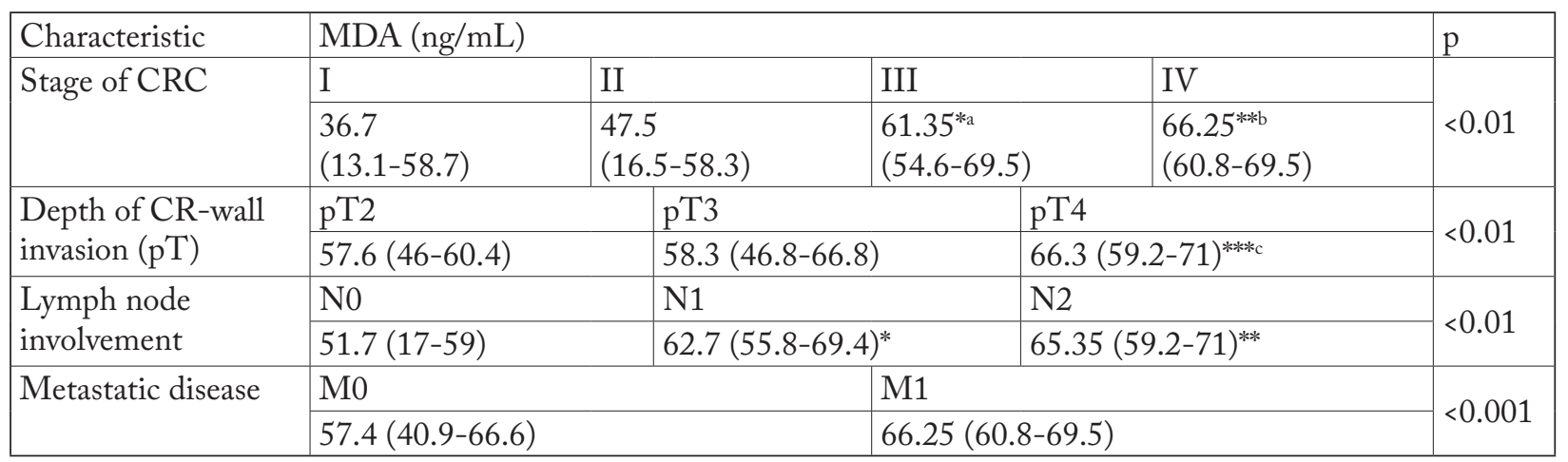

Data are presented as median and interquartile range; ${ }^{*} \mathrm{p}<0.01$, difference between stages II and III and between N0 and N1; ${ }^{\mathrm{p}}<0.05$, difference between stages I and III; ** $<<0.01$, difference between stages II and IV and between N0 and N1; ${ }^{b} p<0.05$, difference between stages I and IV; ${ }^{*} \mathrm{p}<0.01$, difference between $\mathrm{pT} 3$ and $\mathrm{pT} 4 ;{ }^{\mathrm{c}}<0.05$, difference between $\mathrm{pT} 2$ and $\mathrm{pT} 4$; MDA = malondialdehyde; $\mathrm{CRC}=$ colorectal cancer

Table 3. Independent predictors of colorectal cancer progression

\begin{tabular}{|c|c|c|c|c|c|c|c|}
\hline & \multirow{2}{*}{ B } & \multirow{2}{*}{ SE } & \multirow{2}{*}{ Beta } & \multirow{2}{*}{$\mathrm{t}$} & \multirow{2}{*}{$\mathrm{p}$} & \multicolumn{2}{|c|}{ CI 95.0\% } \\
\hline & & & & & & lower & higher \\
\hline Constant & -1.711 & 0.692 & & -2.472 & 0.015 & -3.083 & -0.339 \\
\hline MDA & 0.022 & 0.004 & 0.324 & 5.772 & 0.000 & 0.014 & 0.029 \\
\hline \multicolumn{8}{|c|}{ Dependent variable: CRC stage } \\
\hline Constant & 2.782 & 0.985 & & 2.825 & 0.006 & 0.824 & 4.740 \\
\hline MDA & 0.011 & 0.003 & 0.378 & 3.418 & 0.001 & 0.005 & 0.017 \\
\hline \multicolumn{8}{|c|}{ Dependent variable: depth of CR-wall invasion (pT) } \\
\hline Constant & -2.143 & 1.149 & & -1.865 & 0.066 & -4.426 & 0.141 \\
\hline MDA & 0.015 & 0.004 & 0.382 & 3.967 & 0.000 & 0.007 & 0.022 \\
\hline \multicolumn{8}{|c|}{ Dependent variable: carcinoma infiltration of lymph nodes } \\
\hline Constant & -1.114 & 0.635 & & -1.753 & 0.083 & -2.377 & 0.149 \\
\hline MDA & 0.004 & 0.002 & 0.188 & 2.109 & 0.038 & 0.000 & 0.008 \\
\hline
\end{tabular}

$\mathrm{SE}=$ standard error; $\mathrm{CI}=$ confidence interval; $\mathrm{MDA}=$ malondialdehyde $\mathrm{CRC}=$ colorectal cancer

Malondialdehyde, a product of lipid peroxidation, as an indicator of oxidative activity was monitored during the progression of CRC. It was confirmed that the MDA concentration increased during progression of the malignant diseases of the colon, especially in its third stage (Table 2). In comparison to the control group, serum concentration of MDA did not differ significantly in the first CRC stage (47.5 (16.5-58.3 vs. $36.7(13.1-58.7) \mathrm{ng} / \mathrm{mL}, \mathrm{p}>0.05)$, but it was significantly higher in the CRC second stage $(\mathrm{p}<0.05)$. In the third stage of the disease, serum MDA concentration was significantly higher as compared to the sec- ond stage $(\mathrm{p}<0.01)$, but not significantly different compared to the fourth stage of the disease (Table 2).

The recorded dynamics of change of this parameter according to depth of CR-wall invasion $(\mathrm{pT})$ indicated that serum MDA concentration was significantly higher in pT4 group as compared to pT3 group $(\mathrm{p}<0.01)$ and $\mathrm{pT} 2$ group of CRC patients $(\mathrm{p}<0.05)$, while there was no difference in serum MDA level between pT2 and pT3 groups of CRC patients (Table 2).

The mean levels of MDA were low in patients with no lymph node infiltration by cancerous tissue (N0 group). A higher MDA level was recorded in N1 group 
as compared to N0 group of CRC patients ( $\mathrm{p}<0.001)$, while there was no significant difference in serum concentration of MDA between the N1 and N2 groups (Table 2).

Analysis of MDA in serum of CRC patients suggested that the mean concentration of the oxidative stress biomarkers was significantly higher in patients with metastatic disease than in those without metastasis (57.4 (40.9-66.6) vs. 66.25 (60.8-69.5) $\mathrm{ng} / \mathrm{mL}$, $\mathrm{p}<0.001)$.

The multivariate regression analysis showed that serum MDA concentration was an independent risk factor for the stage of CRC, as well as an independent positive predictor of the depth of $\mathrm{CR}$-wall invasion $(\mathrm{pT})$, carcinoma infiltration of lymph nodes, and the presence of metastasis (Table 3 ).

\section{Discussion}

Colorectal cancer is one of the leading causes of death worldwide. Five-year survival is about $90 \%$ in patients with early stages of cancer, but decreases to less than $10 \%$ in patients with distant metastases ${ }^{8}$. In addition, $25 \%$ to $40 \%$ of patients undergoing curative surgery for localized CRC have a relapse or develop metastases.

Controlling CRC is performed by well-known clinical prognostic factors, including age, gender, cancer embryonic antigen biomarker, tumor differentiation, tumor stage, lymphovascular invasion, perineural invasion, and lymph nodes. The fact is that today's clinical-pathologic indicators cannot predict the outcome of the disease. Therefore, in recent years, significant efforts have been made to find new markers of prognosis and selective approach to therapy.

Due to the high presence of lipids in the cell membrane and membrane subcellular organelles, they are the site where oxidative damage to lipids begins. Lipid peroxidation results in a variety of degradation products, including MDA, which is an indicator of lipid peroxidation and oxidative stress. The target site of MDA action is guanine in DNA, which can cause mutagenic damages, and evidence indicates that they may contribute to cancer, including $\mathrm{CRC}^{9}$. Results by Skrzydlewska et al. point that the products of lipid peroxidation, such as MDA, are increased in CRC tissue $^{10}$. Tahan et al. ${ }^{11}$ and Liu et al. ${ }^{12}$ found in animal models that the levels of MDA were significantly in- creased in colitis, inflammation, and even before CRC development, and that the use of antioxidants could alleviate the severity of colitis by reducing the MDA concentration. The research by Leung et al. suggests that the concentration of MDA in serum is much higher in patients with advanced unresectable CRC than in those with primary localized $\mathrm{CRC}^{13}$.

In our study, measuring serum MDA concentration in patients with various $\mathrm{CRC}$ stages we found the concentration of this oxidative stress marker to significantly increase to the third stage of the disease and as such persisted into the fourth stage of the disease. Similar results have been reported by Surinenaite et al., who found the concentration of MDA in serum of patients with CRC to be significantly higher in the third stage of the disease as compared to the second stage, and to have decreased significantly after surgical treatment when compared with the preoperative level ${ }^{14}$.

In relation to the depth of tumor invasion (pT), significantly higher levels of MDA were recorded in serum of pT4 group patients as compared to pT3 and pT2 groups, indicating oxidative stress increase with the increase in the histopathologic tumor size. Serum MDA was also confirmed as a significant independent positive predictor of the depth of tumor invasion in the intestinal wall, and an independent positive predictor of lymph node infiltration by cancer tissue, as well as the occurrence of metastatic disease. All these facts suggest a high cytotoxic potential of MDA, which allows it to act as a carcinogenic agent and promoter of CRC development and progression. Gopčević et al. found that lipid peroxidation increased in all CRC stages as compared to the control group, but with no significant differences among the stages of the disease ${ }^{15}$. Recent studies point out that the oxidative status expression is caused by reduction of the potential antioxidant defense ${ }^{16}$.

\section{Conclusion}

A significant increase in serum concentrations of $\mathrm{MDA}$ in relation to the $\mathrm{CRC}$ stage, depth of $\mathrm{CR}$-wall invasion and presence of metastatic disease indicates a connection of MDA with carcinogenesis and progression of CRC. Assessing the level of oxidative stress expression by measuring serum MDA concentration could be useful in monitoring the effects of treatment of CRC, which can be the subject of future research. 


\section{References}

1. Haggar FA, Boushey RP. Colorectal cancer epidemiology: incidence, mortality, survival, and risk factors. Clin Colon Rectal Surg.2009;22:191-7.http://dx.doi.org/10.1055/s-0029-1242458

2. Kawanishi S, Hiraku Y, Pinlaor S, Ma N. Oxidative and nitrative DNA damage in animals and patients with inflammatory diseases in relation to inflammation-related carcinogenesis. Biol Chem. 2006;387:365-72.

http://dx.doi.org/10.1515/BC.2006.049

3. Barrera G, Pizzimenti S, Dianzani MU. Lipid peroxidation: control of cell proliferation, cell differentiation and cell death. Mol Aspects Med. 2008;29:1-8. http://dx.doi.org/ 10.1016/j. mam.2007.09.012

4. Barrera G. Oxidative stress and lipid peroxidation products in cancer progression and therapy. ISRN Oncol. 2012;2012: 137289. http://dx.doi.org/10.5402/2012/137289

5. Štefan L, Tepšić T, Zavidić T, Urukalo M, Tota D, Domitrović R. Lipid peroxidation - causes and consequences. Medicina. 2007;43:84-93.

6. Salzman R, Pacal L, Tomand1 J, Kankova K, Tothova E, Gal B, et al. Elevated malondialdehyde correlates with the extent of primary tumor and predicts poor prognosis of oropharyngeal cancer. Anticancer Res. 2009;29:4227-31.

7. Zalewski B. Levels of v5 and v6 CD44 splice variants in serum of patients with colorectal cancer are not correlated with $\mathrm{pT}$ stage, histopathological grade of malignancy and clinical features. World J Gastroenterol. 2004;10:583-5. http://www.wjgnet.com/1007-9327/10/583.asp

8. O'Connell JB, Maggard MA, Ko CY. Colon cancer survival rates with the new American Joint Committee on Cancer sixth edition staging. J Natl Cancer Inst. 2004;96:1420-5. http:// dx.doi.org/10.1093/jnci/djh275

9. Obtułowicz T, Winczura A, Speina E, Swoboda M, Janik J, Janowska B, et al. Aberrant repair of etheno-DNA adducts in leukocytes and colon tissue of colon cancer patients. Free Radic Biol Med. 2010;49:1064-71.

doi: 10.1016/j.freeradbiomed.2010.06.027

10. Skrzydlewska E, Sukowski S, Koda M, Zalewski B, KanczugaKoda L, Sulkowska M. Lipid peroxidation and antioxidant status in colorectal cancer. World J Gastroenterol. 2005;1:403-6. http://dx.doi.org/ 10.3748/wjg.v11.i3.403

11. Tahan G, Gramignoli R, Marongiu F, Aktolga S, Cetinkaya A, Tahan V, et al. Melatonin expresses powerful anti-inflammatory and antioxidant activities resulting in complete improvement of acetic-acid-induced colitis in rats. Dig Dis Sci. 2011; 56:715-20. http://dx.doi.org/10.1007/s10620-010-1364-5

12. Liu X, Wang J. Anti-inflammatory effects of iridoid glycosides fraction of Folium syringae leaves on TNBS-induced colitis in rats. J Ethnopharmacol. 2010;133:780-7. http://dx.doi.org/10.1371/journal.pone.0024740

13. Leung EY, Crozier JE, Talwar D, O'Reilly DS, McKee RF, Horgan PG, et al. Vitamin antioxidants, lipid peroxidation, tumour stage, the systemic inflammatory response and survival in patients with colorectal cancer. Int J Cancer. 2008;123:2460-4. http://dx.doi.org/10.1002/ijc.23811

14. Surinenaite B, Prasmickiene G, Milasiene V, Stratilatovas E, Didziapetriene J. The influence of surgical treatment and red blood cell transfusion on changes in antioxidative and immune system parameters in colorectal cancer patients. Medicina (Kaunas). 2009;45:785-91.

15. Gopčević KR, Rovčanin BR, Tatić SB, Krivokapić ZV, Gajić MM, Dragutinović VV. Activity of superoxide dismutase, catalase, glutathione peroxidase, and glutathione reductase in different stages of colorectal carcinoma. Dig Dis Sci. 2013;58: 2646-52. http://dx.doi.org/10.1007/s10620-013-2681-2

16. Stone WL, Krishnan K, Campbell SE, Palau VE. The role of antioxidants and pro-oxidants in color cancer. World J Gastrointest Oncol. 2014;6:55-66. http://dx.doi.org/ 10.4251/wjgo.v6.i3.55

Sažetak

\section{ODNOS IZMEĐU SERUMSKE RAZINE MALONDIALDEHIDA I PROGRESIJE KOLOREKTALNOG KARCINOMA}

\section{Rašić, A. Rašić, G. Akšamija i S. Radović}

Cilj istraživanja bio je procijeniti razinu koncentracije malondialdehida (MDA) u serumu i njegove povezanosti sa stadijem i histopatološkom veličinom kolorektalnog karcinoma (CRC). Stotinu i dva bolesnika podvrgnuta kirurškom liječenju CRC između siječnja 2014. i prosinca 2015. godine bili su uključeni u ovu presječnu studiju. Bolesnici su bili podijeljeni u četiri skupine (stadiji I.-IV.) prema klasifikaciji TNM. Kontrolnu skupinu predstavljalo je 30 ispitanika bez znakova malignih i upalnih bolesti. U svakog bolesnika prijeoperacijski su uzeti uzorci krvi za određivanje koncentracije MDA pomoću imuno testa ELISA. Razine MDA u serumu su se postupno povećavale u bolesnika s CRC, dosegnuvši najvišu vrijednost u četvrtoj fazi CRC. Serumske koncentracije MDA bile su značajno više u skupini pT4 u odnosu na skupine pT3 i pT2 bolesnika s CRC $(p<0,01)$. Utvrđene su značajno više razine MDA u skupinama N1 i N2 u odnosu na skupinu N0, kao i kod bolesnika $s$ metastatskom bolešću u usporedbi s bolesnicima bez metastaza $(\mathrm{p}<0,001)$. U zaključku, napredovanje CRC povezano je sa značajnim porastom razine MDA u serumu.

Ključne riječi: Kolon, tumori; Oksidativni stres; Malondialdehid; Presječno istraživanje 